\title{
Illiteracy: A Threat to Peace in Federally Administrated Tribal Areas (FATA) of Pakistan
}

\author{
Alamgeer Khan', Mushtaq Ahmad Jadoon², \\ Intikhab Alam ${ }^{3}$, Muhammad Jawad ${ }^{4}$, and Ubaid ur \\ Rehman $^{5}$ \\ The University of Agriculture, Peshawar, Pakistan
}

\begin{abstract}
Pakistan's decision of participating in the war on terror has put the entire country especially FATA on the mercy of extremist and terrorists. The current layer of terrorism and extremism has destroyed the peaceful traditional tribal society. The present study was conducted during 2013 to probe the effect of illiteracy on peace in the war-affected zone FATA. The major findings of the study reveal that illiteracy ratio was high at FATA, making FATA safe haven for militants and it was one of the main cases of terrorism, leading to violence, making the illiterate youth and madrasa students more vulnerable to militancy. Furthermore lacks of interest in education, dysfunctional education institution, and preference to madrasa education were also the variables, which were affecting peace in FATA. The study also reveals that in the presence of illiteracy sustainable peace is not possible in FATA
\end{abstract}

Keywords. peace, threat, illiteracy, FATA,

Federally Administrated Tribal Areas (FATA) is constitutionalized territory of Pakistan. The area is composed of seven administrative units (agencies), namely Khyber, Kurram, Bajaur, Mohmand, Orakzai, North and South Waziristan and six Frontier Regions (FR Peshawar, FR Kohat, FR Tank, FR Banuu, FR Lakki and FR Dera Ismail Khan). According to the 1998 Pakistan census, FATA's

\footnotetext{
${ }^{1}$ Lecturer, Rural Sociology Department, The University of Agriculture Peshawar

${ }^{2}$ Lecturer, Rural Sociology Department, The University of Agriculture Peshawar

${ }^{3}$ Lecturer, Rural Sociology Department, The University of Agriculture Peshawar

${ }^{4}$ Lecturer, Rural Sociology Department, The University of Agriculture Peshawar

${ }^{5}$ Lecturer, Rural Sociology Department, The University of Agriculture Peshawar
} 
total population is 3.3 million. The area is run under British colonel system Frontier Crime Regulations (FCR) making it isolates from the rest of the country.

FATA has remained deprived of many political and legal rights resulting loose write of state in the area. FATA is one of the most undeveloped areas where $60 \%$ population lives in poor conditions with only $17 \%$ literacy rate (Ahmar, 2008). The low condition of life and low literacy rate has made FATA ungoverned and uncontrolled region Shinwari (2008). FATA is a male dominated society with high rate of poverty, unemployment and illiteracy. The region has been neglected by successive governments; this has created numerous political, security and economic problems which has depressed the people especially young men in FATA. In the presence of such social evils many of the FATA people are turning to fundamentalist religion. Islamist extremists groups in the region are powerful and potentially dangerous, making security volatile as result many conflicts has been accord between Taliban and security forces (Camp, 2010). The main factors leading to terrorism in FATA are lack of economic opportunities, unequal access to avenues for social and economic mobilization, Corruption, defective education system, poverty, unemployment, illiteracy, easy access to firearms, bad governance, volatile geopolitical situation, marginalization of the rural areas, and non-availability of justice (Ali, 2010). The alternate education available in FATA is in form of madrassa, since the 1950s, the border areas had seen a large increase in the number of madrassas, many reportedly funded by Saudi Arabia. Many refugee children, as well as poor Pakistanis, attended these madrassas. Although all madrassas are not spreading extremism and terrorism but some madrassa have been reported recruiting students for terrorism(KEMP, 2008).

\section{Method}

The study was based on primary data; collected from the 
residents of the two war's affected tribes (Ali sherZai and MasoZai) having 4495 and 3176 households respectively (1998 Census Report), 366 samples were obtained by using Sekaran table (2003).

After the collection of data, statistical package for social sciences (SPSS) was used. The data was analyzed by using uni-variate and bivariate techniques of data analysis. At uni-variate level frequencies and percentages were worked out, whereas, at bi-variate level dependent variable was indexed and cross tabbed to test the association with independent variables for further details see table 1 .

Table 1

Conceptual Frame Work

\begin{tabular}{|c|c|}
\hline Independent Variable & Dependent Variable \\
\hline Illiteracy & Peace \\
\hline
\end{tabular}

Table 2

\section{Results}

Perceived Current Status of Peace in FATA

\begin{tabular}{lccc}
\hline Statement & Agree & Disagree & Not sure \\
\hline $\begin{array}{l}\text { FATA is peaceful } \\
\text { place }\end{array}$ & $38(10.4 \%)$ & $\begin{array}{c}315 \\
(86.1 \%)\end{array}$ & $13(3.6 \%)$ \\
$\begin{array}{l}\text { FATA is under the } \\
\text { shadow of war }\end{array}$ & $312(85.2 \%)$ & $41(11.2 \%)$ & $13(3.6 \%)$ \\
$\begin{array}{l}\text { War/ Terrorism has } \\
\text { affected the lives of }\end{array}$ & $316(86.4 \%)$ & $28(7.7 \%)$ & $22(6.0 \%)$ \\
people of FATA & & & \\
$\begin{array}{l}\text { FATA is not peaceful } \\
\text { after the arrival of } \\
\text { militants }\end{array}$ & $273(74.6 \%)$ & $67(18.3 \%)$ & $26(7.1 \%)$ \\
$\begin{array}{l}\text { There is violence and } \\
\text { terror in FATA }\end{array}$ & $290(79.2 \%)$ & $52(14.2 \%)$ & $24(6.6 \%)$ \\
$\begin{array}{l}\text { Drone attacks are } \\
\text { common in FATA }\end{array}$ & $291(79.5 \%)$ & $50(13.7 \%)$ & $25(6.8 \%)$ \\
\hline
\end{tabular}




\begin{tabular}{|c|c|c|c|}
\hline $\begin{array}{l}\text { FATA is an open } \\
\text { hide out/safe heavens } \\
\text { of militants }\end{array}$ & $146(39.9 \%)$ & $\begin{array}{c}198 \\
(54.1 \%)\end{array}$ & $22(6.0 \%)$ \\
\hline $\begin{array}{l}\text { Militants movement } \\
\text { can be freely observe } \\
\text { in FATA }\end{array}$ & $98(26.8 \%)$ & $\begin{array}{c}261 \\
(71.3 \%)\end{array}$ & $7(1.9 \%)$ \\
\hline $\begin{array}{l}\text { Peace is the major } \\
\text { demand of FATA } \\
\text { people }\end{array}$ & $326(89.1 \%)$ & $17(4.6 \%)$ & $23(6.3 \%)$ \\
\hline $\begin{array}{l}\text { There should be } \\
\text { urgent efforts for } \\
\text { peace in FATA }\end{array}$ & $341(93.2 \%)$ & $16(4.4 \%)$ & $9(2.5 \%)$ \\
\hline $\begin{array}{l}\text { There are high } \\
\text { prospects of peace in } \\
\text { near future }\end{array}$ & $43(11.7 \%)$ & $81(22.1 \%)$ & $242(66.1 \%)$ \\
\hline
\end{tabular}

Table 2 major results reveals that majority of the respondents $86.1 \%$ believed that peace does not exist in FATA, $85.2 \%$ and $86.4 \%$ of the respondents reported that FATA is under the shadow of war and war has affected the lives of FATA people respectively. Another $86.4 \%$, $74.6 \%, 79.2 \%, 79.5 \%, 39.9 \%$ of the respondents also stated that militant has destroyed the peace of FATA, has brought terror, violence and drone attacks in the area respectively. Another $39.9 \%$ and $26.8 \%$ of the respondents endorsed the success of military operation against miscreants destroying safe heavens of militants and restricting their free movement at FATA respectively. A sizeable number of respondents 89.1 $\%, 93.2 \%, 11.7 \%$ were prioritizing and demanding urgent efforts for peace in the region but unfortunately they themselves are not sure for having it in the near future respectively. 
Table 3

Illiteracy as Factor affecting Peace in FATA

\begin{tabular}{|c|c|c|c|}
\hline Statement & Agree & Disagree & Not sure \\
\hline Low literacy ratio & $\begin{array}{c}313 \\
(85.5 \%)\end{array}$ & $15(4.1 \%)$ & $38(10.4 \%)$ \\
\hline Lack of interest in education & $57(15.6 \%)$ & $\begin{array}{c}279 \\
(76.2 \%)\end{array}$ & $30(8.2 \%)$ \\
\hline $\begin{array}{l}\text { Dysfunctional education } \\
\text { institution }\end{array}$ & $\begin{array}{c}244 \\
(66.7 \%)\end{array}$ & $\begin{array}{c}103 \\
(28.1 \%)\end{array}$ & $19(5.2 \%)$ \\
\hline $\begin{array}{l}\text { Illiteracy Is the main case of } \\
\text { terrorism }\end{array}$ & $\begin{array}{c}313 \\
(85.5 \%)\end{array}$ & $25(6.8 \%)$ & $28(7.7 \%)$ \\
\hline Illiteracy leads to violence & $216(59 \%)$ & $55(15 \%)$ & $95(26 \%)$ \\
\hline $\begin{array}{l}\text { Illiterate youth are more } \\
\text { vulnerable to militancy }\end{array}$ & $\begin{array}{c}271 \\
(74.0 \%)\end{array}$ & $51(13.9 \%)$ & $44(12.1 \%)$ \\
\hline $\begin{array}{l}\text { Tribal gives preference to } \\
\text { madrasa education on formal } \\
\text { education }\end{array}$ & $\begin{array}{c}207 \\
(56.6 \%)\end{array}$ & $\begin{array}{c}153 \\
(41.8 \%)\end{array}$ & $6(1.6 \%)$ \\
\hline $\begin{array}{l}\text { Preference to madrasa } \\
\text { education due to religious } \\
\text { attachments }\end{array}$ & $\begin{array}{c}301 \\
(82.2 \%)\end{array}$ & $\begin{array}{c}56(15.3 \\
\%)\end{array}$ & $9(2.5 \%)$ \\
\hline $\begin{array}{l}\text { madrasa students are more } \\
\text { vulnerable to militancy. }\end{array}$ & $267(73 \%)$ & $72(19.6 \%)$ & $27(7.4 \%)$ \\
\hline $\begin{array}{l}\text { Lack of education making } \\
\text { FATA safe havens for } \\
\text { militants }\end{array}$ & $\begin{array}{c}275 \\
(75.1 \%)\end{array}$ & $71(19.4 \%)$ & $20(5.5 \%)$ \\
\hline
\end{tabular}




\begin{tabular}{lccc}
\hline $\begin{array}{l}\text { Presence of low literacy ratio } \\
\text { and sustainable peace. }\end{array}$ & 270 & $52(14.2 \%)$ & $44(12.0 \%)$ \\
& $(73.8 \%)$ & &
\end{tabular}

The major findings of table 3 states that majority of the respondents $85.5 \%, 15.6 \%$ and $66.7 \%$ believed that FATA is low literacy zone due to lack of interested in education and dysfunctional education's institution respectively. The majority of the respondents $85.5 \%, 59 \%$ and $74.0 \%$ reported that illiteracy is one of the main causes of terrorism, leads to violence and illiterate youth are more vulnerable to militancy respectively. Furthermore $56.6 \%, 82.2 \%$ and $73 \%$ of the respondents reported that tribal people give preference to madrasa education, due to religious attachments and also reported that madrasa students are vulnerable to militancy respectively. A sizable number of respondents $75.1 \%$ and $73.8 \%$ reported that low literacy ratio has converted FATA into safe havens for militants and in the presence of low literacy ratio sustainable peace could not be archived respectively.

Table 5

Illiteracy as factor affecting peace in FATA

\begin{tabular}{|c|c|c|c|c|}
\hline Variables & Yes & No & $\begin{array}{l}\text { Don't } \\
\text { Know }\end{array}$ & $x^{2}(p)$ \\
\hline \multicolumn{5}{|c|}{ Low literacy ratio } \\
\hline Agree & $\begin{array}{l}247 \\
(67.5 \%)\end{array}$ & $\begin{array}{l}41 \\
(11.2 \%)\end{array}$ & $25(6.8 \%)$ & $\mathbf{x}^{2}=18.96$ \\
\hline Disagree & $8(2.2 \%)$ & $1(0.3 \%)$ & $6(1.6 \%)$ & $(.001)$ \\
\hline Not sure & $25(6.8 \%)$ & $7(1.9 \%)$ & $6(1.6 \%)$ & \\
\hline \multicolumn{5}{|c|}{ Lack of interest in education } \\
\hline Agree & 49 & $6(1.6 \%)$ & $2(0.5 \%)$ & $x^{2}=8.26$ \\
\hline
\end{tabular}


Illiteracy: A Threat to Peace in Federally Administrated Tribal Areas (FATA).... 67

\begin{tabular}{|c|c|c|c|c|}
\hline \multirow[b]{2}{*}{ Disagree } & \multicolumn{3}{|l|}{$(13.4 \%)$} & \multirow[t]{3}{*}{$(.082)$} \\
\hline & $\begin{array}{l}208 \\
(56.8 .0 \%)\end{array}$ & $\begin{array}{l}37 \\
(10.1 \%)\end{array}$ & $34(9.3 \%)$ & \\
\hline Not sure & $23(6.3 \%)$ & $6(1.6 \%)$ & $1(0.3 \%)$ & \\
\hline \multicolumn{5}{|c|}{ Dysfunctional education institution } \\
\hline Agree & $\begin{array}{l}192 \\
(52.5 \%)\end{array}$ & $31(8.5 \%)$ & $21(5.7 \%)$ & \multirow{3}{*}{$\begin{array}{c}x^{2}=8.88 \\
(.06)\end{array}$} \\
\hline Disagree & $\begin{array}{l}71 \\
(19.4 \%)\end{array}$ & $16(4.4 \%)$ & $16(4.4 \%)$ & \\
\hline Not sure & $17(4.6 \%)$ & $2(0.5 \%)$ & $0(0.0 \%)$ & \\
\hline \multicolumn{5}{|c|}{ Militant hit formal education infrastructure } \\
\hline Agree & $\begin{array}{l}140 \\
(38.3 \%)\end{array}$ & $26(7.1 \%)$ & $13(3.6 \%)$ & \multirow{3}{*}{$\begin{array}{c}x^{2}=4.71 \\
(.31)\end{array}$} \\
\hline Disagree & $\begin{array}{l}109 \\
(29.8 \%)\end{array}$ & $18(4.9 \%)$ & $21(5.7 \%)$ & \\
\hline Not sure & $31(8.5 \%)$ & $5(1.6 \%)$ & $3(0.8 \%)$ & \\
\hline \multicolumn{5}{|c|}{ Illiteracy the main case of terrorism } \\
\hline Agree & $\begin{array}{l}238 \\
(65.0 \%)\end{array}$ & $\begin{array}{l}43 \\
(11.7 \%)\end{array}$ & $32(8.7 \%)$ & \multirow{3}{*}{$\begin{array}{c}x^{2}=11.64 \\
(.02)\end{array}$} \\
\hline Disagree & $25(6.8 \%)$ & $0(0.0 \%)$ & $0(0.0 \%)$ & \\
\hline Not sure & $17(4.6 \%)$ & $6(1.6 \%)$ & $5(1.4 \%)$ & \\
\hline \multicolumn{5}{|c|}{ Illiterate Youth are more vulnerable to militancy } \\
\hline Agree & $\begin{array}{l}205 \\
(56.0 \%)\end{array}$ & $\begin{array}{l}35 \\
(9.6 \%)\end{array}$ & $31(8.5 \%)$ & \multirow{3}{*}{$\begin{array}{c}x^{2}=8.18 \\
(.06)\end{array}$} \\
\hline Disagree & $35(9.6 \%)$ & $10(2.7 \%)$ & $6(1.6 \%)$ & \\
\hline Not sure & $\begin{array}{l}40 \\
(10.9 \%)\end{array}$ & $4(1.1 \%)$ & $0(0.0 \%)$ & \\
\hline \multicolumn{5}{|c|}{ Illiteracy leads to violence } \\
\hline Agree & $\begin{array}{l}159 \\
(43.4 \%)\end{array}$ & $34(9.3 \%)$ & $23(6.3 \%)$ & \multirow{3}{*}{$\begin{array}{c}x^{2}=7.96 \\
(.09)\end{array}$} \\
\hline Disagree & $\begin{array}{l}40 \\
(10.9 \%)\end{array}$ & $10(2.7 \%)$ & $5(1.4 \%)$ & \\
\hline Not sure & $81(21.1 \%)$ & $5(1.4 \%)$ & $9(2.5 \%)$ & \\
\hline \multicolumn{5}{|c|}{ Preference to madrasa education on formal education } \\
\hline Agree & $\begin{array}{l}150 \\
(41.0 \%)\end{array}$ & $\begin{array}{l}37 \\
(10.1 \%)\end{array}$ & $20(5.5 \%)$ & $\mathbf{x}^{2}==11.8$ \\
\hline
\end{tabular}

Peshawar Journal of Psychology and Behavioral Sciences, 2015, Vol. 1, No. 1, 61-71 


\begin{tabular}{|c|c|c|c|c|}
\hline Disagree & $\begin{array}{l}127 \\
(34.7 \%)\end{array}$ & $12(3.3 \%)$ & $14(3.8 \%)$ & \multirow[t]{2}{*}{$\begin{array}{l}5 \\
(.01)\end{array}$} \\
\hline Not sure & $3(0.8 \%)$ & $0(0.0 \%)$ & $3(0.8 \%)$ & \\
\hline \multicolumn{5}{|c|}{ madrasa education is preferred because of religious attachments } \\
\hline Agree & $\begin{array}{l}225 \\
(61.5 \%)\end{array}$ & $\begin{array}{l}45 \\
(12.3 \%)\end{array}$ & $31(8.5 \%)$ & \multirow{2}{*}{$\begin{array}{l}x^{2}=5.32 \\
(.25)\end{array}$} \\
\hline Disagree & $\begin{array}{l}55 \\
(12.6 \%)\end{array}$ & $9(1.1 \%)$ & $8(1.6 \%)$ & \\
\hline Not sure & $9(2.5 \%)$ & $0(0.0 \%)$ & $0(0.0 \%)$ & \\
\hline \multicolumn{5}{|c|}{ madrasa students are more vulnerable to militancy } \\
\hline Agree & $\begin{array}{l}210 \\
(57.4 \%)\end{array}$ & $31(8.5 \%)$ & $26(7.1 \%)$ & \multirow{3}{*}{$\begin{array}{c}x^{2}=10.54 \\
\quad(.03)\end{array}$} \\
\hline Disagree & $\begin{array}{l}55 \\
(15.0 \%)\end{array}$ & $9(2.5 \%)$ & $8(2.2 \%)$ & \\
\hline Not sure & $15(4.1 \%)$ & $9(2.5 \%)$ & $3(0.8 \%)$ & \\
\hline \multicolumn{5}{|c|}{$\begin{array}{l}\text { Tribal People prefer madrasa education due to low quality of formal } \\
\text { education system }\end{array}$} \\
\hline Agree & $\begin{array}{l}41 \\
(11.2 \%)\end{array}$ & $9(2.5 \%)$ & $5(1.4 \%)$ & \multirow{3}{*}{$\begin{array}{l}x^{2}=3.00 \\
\quad(.55)\end{array}$} \\
\hline Disagree & $\begin{array}{l}229 \\
(62.6 \%)\end{array}$ & $\begin{array}{l}37 \\
(10.1 \%)\end{array}$ & $32(8.7 \%)$ & \\
\hline Not sure & $10(2.7 \%)$ & $3(.8 \%)$ & $0(0.0 \%)$ & \\
\hline \multicolumn{5}{|c|}{$\begin{array}{l}\text { Due to lack of education FATA has become a safe havens for } \\
\text { militants }\end{array}$} \\
\hline Agree & $\begin{array}{l}157 \\
(42.9 \%)\end{array}$ & $\begin{array}{l}109 \\
(29.8 \%)\end{array}$ & $9(2.5 \%)$ & \multirow{3}{*}{$\begin{aligned} x^{2} & =10.67 \\
& (.03)\end{aligned}$} \\
\hline Disagree & $\begin{array}{l}45 \\
(12.3 \%)\end{array}$ & $25(6.8 \%)$ & $1(0.3 \%)$ & \\
\hline Not sure & $10(2.7 \%)$ & $7(1.9 \%)$ & $3(0.8 \%)$ & \\
\hline
\end{tabular}

Presence of low literacy ratio and impossibility of sustainable peace. 


\begin{tabular}{lllll}
\hline Agree & $\begin{array}{l}217 \\
(59.3 \%)\end{array}$ & $31(8.5 \%)$ & $22(6.0 \%)$ & \\
Disagree & 38 & & & $x^{2}=12.38$ \\
& $(10.4 \%)$ & $8(2.2 \%)$ & $6(1.6 \%)$ & $(.01)$ \\
Not sure & $25(6.8 \%)$ & $10(2.7 \%)$ & $9(2.5 \%)$ & \\
\hline
\end{tabular}

Table 5 shows the association of illiteracy and peace, significant association was observed between variable peace and low literacy ratio in FATA $(\mathrm{P}=.001)$, lack of interest in education $(\mathrm{P}=.082)$, dysfunctional education institution $(\mathrm{P}=.064)$, illiteracy as the main case of terrorism $(\mathrm{P}=.020)$, illiterate youth are more vulnerable to militancy $(\mathrm{P}=.066)$, illiteracy leads to violence $(\mathrm{P}=.093)$, preference to madrasa education $(\mathrm{P}=0.18)$, madrasa students are more vulnerable to militancy $(\mathrm{P}=.032)$ lack of education making FATA safe havens for militants $(\mathrm{P}=.030)$ and the impossibility of peace in the presence of low literacy ratio $(\mathrm{P}=.015)$ whereas those found insignificant include militants hitting formal education infrastructure $(\mathrm{P}=.318)$, preference of madrasa education due to religious sentiments $(\mathrm{P}=.255)$ and preference to madrasa education due to low quality of formal education system $(\mathrm{P}=.557)$.

\section{Discussion}

Peace has become one of the main global challenges faced by most of the nations. After 9/11 peace has become one of the burning issues of FATA. "Literacy is a bridge from misery to hope. It is a tool for daily life in modern society. It is a bulwark against poverty and a building block of development, an essential complement to investments in roads, dams, clinics, and factories. Literacy is a platform for democratization and a vehicle for the promotion of cultural and national identity. Especially for girls and women, it is an agent of family health and nutrition. For everyone everywhere, literacy is, finally, the road to human progress and the means through which every man, woman, and child can realize his or her full potential." (Kofi Annan)

Illiteracy is one of the key factors molding the attitudes of human towards peaceful productive activities. The results as a whole 
reveal that low literacy ratio, lack of interest in education, dysfunctional education institution, preference to madrasa education and lack of education making FATA safe havens for militants were affecting peace while the variable such as militants hitting formal education infrastructure, illiteracy as main cause of terrorism, illiteracy leads to violence, illiterate youth are more vulnerable to militancy, preference of madrasa education due to religious sentiments, madrasa students are more vulnerable to militancy had no significant association.

\section{Conclusion and Recommendations}

The study concluded significant association between dependent variable peace and sub variables of independent variable illiteracy these included low literacy ratio in FATA, Tribal's lack of interest in education, dysfunctional education institution, illiteracy as the main case of terrorism, Illiteracy leads to violence, illiterate Youth are more vulnerable to militancy, preference to madrasa education, madrasa students' more vulnerable to militancy, lack of education making FATA safe havens for militants and the impossibility of peace in the presence of low literacy ratio..

To overcome the current problems in FATA government and private sector should provide free education to the inhabitants of FATA. The quality of education should not be compromised on any level. Importance should also be given on adult education in FATA. The illiterate youth should be given technical education to integrate them in the reestablishment of FATA. FATA students (formal and madrassas) should be provided scholarships and recreational facilities. Madrasas in FATA should be registered with government and policy should be implemented to restrict anyone for misleading and wrong interpretation of Islam

\section{References}


Illiteracy: A Threat to Peace in Federally Administrated Tribal Areas (FATA).....

Ahmar, M. (2008). "How serious is the threat from Pakistan's tribal areas".http://www.dawn.com/weekly/encounter/20080419/enco unter3.htm

Ali, R. (2010). "Militancy and socioeconomic problems: a case study of Pakistan”. www. issi.org.pk/publicationfiles/1299051742_14233891.pdf

Kemp, Robert. 2008. "Religious Extremism and Militancy in the Pashtun Areas of Afghanistan and Pakistan". BC Journal of International Affairs. Volume 11, Spring 2008.

Camp, (2010).“Constitution status of FATA”. www. camp. org. pk/pdfs/ Fata\%20Dialogue\%201.pdf

Sekaran (2003), Research method for business. Hermitage public series, USA.

Shinwari, N.A. (2008). "Understanding FATA Attitude Towards Governance, Religion \& Society in Pakistan Federally Administrated Tribal Are”. Pp. 75-81 